UDK 657.338

DOI: 10.31651/2076-5843-2019-1-124-130

Khalleefah Ahmed Mohammed,

$\mathrm{PhD}$,

Simon Kuznets Kharkiv National

University of Economics

ORCID ID: https://orcid.org/0000-0002-2762-0774

alryaniahmad@yahoo.com

\title{
STRATEGIC REPORT AS INFORMATION AND ANALYTICAL BASIS FOR STRATEGIC MANAGEMENT
}

Strategic accounting is very important element of effective strategic management. To perform its function strategic accounting information should correspond to strategic goals of the firm. To be useful for enterprise stakeholders, strategic accounting information should include information on business valuation, information on enterprise financial and economic security, information on competitive intelligence, and also information on strategy implementation results, which can be assessed by KPI.

The most appropriate form for strategic information preparing is enterprise strategic report, which should be prepared on the year basis as a part of enterprise annual report. But separate element of this report (KPI of strategy implementation results) should be prepared on monthly basis and discussed with strategic planning team according to planning calendar.

Concerning the responsible persons - departments of financial analytics and economic security department should be responsible for strategic report preparation.

Keywords: documentation process; strategic report; strategic accounting information; strategic management; KPI analysis; information on business valuation; information on enterprise financial and economic security; information on competitive intelligence.

Introduction. Process documents reveal a great deal about your business philosophy. Poorly written and out-of-date documents can signal a lack of caring. Current and polished documents empower teams and improve efficiency.

Process documentation is a roadmap for your organization - it helps you identify the current state of a process to know how you can improve it. Any task that is done more than once or completed by multiple people needs to be documented. Doing so provides consistency for your organization and allows you to monitor and revise processes as you go along.

It is especially important to organize documentation process to provide information necessary for strategic management, because information given in documents allows assessing achieved results and making proper correcting actions in order to achieve planned strategic results (Ernst \& Young, 2018).

To meet the requirements of strategic management information should be strategicallyoriented, which means that it should not only include assessment and reflection of enterprise assets, liabilities and financial outcomes in previous reporting periods, but should also take into account such aspects of enterprise activity as: assessment of enterprise outcomes correspondence to enterprise strategic goals, evaluation of enterprise management system effectiveness and other strategic business parameters assessment.

Taking into account the validity of information for taking strategic decisions and strategic results monitoring it is important to determine information necessary at each stage of strategic management for each group of stakeholders, way of its presentation and responsible persons, which will be the main goal of the paper.

Literature review. Analysis of economic literature has shown that most scientists consider strategic reports to be the main source of information used in the strategic management process for taking strategic decisions. 
Thus, the need of strategic reports preparation for raising the efficiency of corporate governance is emphasized by Financial Reporting Council, which has edited Guidance on the Strategic Report (2018) to facilitate the process of strategic reports preparation and to underline strategic information validity for enterprise and its stakeholders.

Strategic report, according to the Guidance on the Strategic Report, is the part of enterprise's annual report together with corporate governance report, directors' remuneration report, financial statements and directors' report. It is considered to provide additional information to financial statements, explaining the sources of enterprise value and way of their management more detailed.

The other vision of strategic reports is given by Keith D. Brouthers and Frans A. Roozen (1999), who discover the frame of strategic information based on Ansoff strategic-success-formula. The scientists consider strategic reports to be the control tool of accounting and to be the separate reports, prepared by accountants according to strategic management needs.

They argue that the content of strategic accounting information should be based on the level of environmental turbulence of enterprise. Depending on the level of enterprise development it can include one of the following reports:

1) Strategic Variance Reports - reports, focused on strategic goals and objectives of enterprise, in which deviation from strategic goals is measured and differences in planned strategic activities are analyzed;

2) Strategic Contribution Reports - contains data gathered over the life of strategic project to measure the impact or success of strategies, by measuring the contribution or progress;

3) Strategic Progress Reports - supply information about future financial commitments for strategic projects; identifies the timing of upcoming financial commitments and the last date of the commitments.

They also underline, that the frequency of reporting depends on the level of enterprise turbulence and can vary from weekly reporting to quarterly.

KPMG Company in its Practical Guide to the Strategic Reports (2014) describes the essence of strategic report as a separate report within the corporate governance statement. It identifies the three basic elements of strategic report, such as: Strategic Management, Business Environment and Business Performance.

Thus it can be assumed that strategic report can be considered to be the part of enterprise annual report, which is the main source of information used in strategic management and includes information needed by managers depending on the turbulence level of enterprise external environment and the needs of enterprise stakeholders.

Purpose of the article. The purpose of the paper is to research the documenting process for strategic accounting information preparing and its role in strategic management system.

The main objectives are the following:

1) To specify the content of each element of strategic accounting information;

2) To identify the content of strategic reports; and

3) To analyze the periods of their presentation frequency.

Basic scientific methods, which will be used to achieve objectives of the paper, such as: analysis, synthesis, comparison and classification.

Results and discussion. An explanation of the purpose of strategic reports is given in the Guidance on the Strategic Report, where it is considered to be providing information for stakeholders and helping them to assess how the directors have performed their duty to promote the success of an enterprise. It also emphasizes the necessity of stakeholders' interests considering, which can have impact on the long-term success of the entity.

The necessity of strategic report to be focused on stakeholders' needs is also underlined in Practical Guide to the Strategic Reports (KPMG, 2014), so the orientation of strategic report on stakeholders should be taken into account in the process of strategic report content defining.

Keith D. Brouthers and Frans A. Roozen (1999) highlight the necessity of analyzing not only internal, but also external environment of enterprise activity, and the need to take strategic enterprise goal into consideration in process of strategic reports forming, but they don't consider the 
needs of different groups of enterprise stakeholders, which is also very important, taking into account the necessity of enterprise to correspond the interests of all stakeholders in the process of strategic management.

An idea concerning the necessity of reflecting information on enterprise business environment, including both - internal and external environment, is also reflected in the Guidance on the Strategic Report (Financial Reporting Council, 2018). But in the Guidance it consists in environmental risks analysis, which is usually connected with enterprise economic security.

Information concerning enterprise economic security is valuable element of strategic information necessary for effective strategic management in conditions of economic instability, so it also must be an element of strategic report. But it should be complemented with assessment of the risk of internal environment for enterprise activity and the risks of enterprise for external environment, which is not included in recommendations of Guidance on the Strategic Report, where only the risks of external environment for enterprise's strategy implementation are proposed to be analyzed.

Guidance on the Strategic Report doesn't give information concerning the peculiarities of strategic accounting information, which include description of documenting process, stakeholders interested in such information receiving and subjects responsible for its preparation. But they have a lot of valuable information concerning content of strategic accounting report.

For example, the idea of describing elements of enterprise value in strategic reports is especially valid for such stakeholders of enterprise as owners and investors, who are interested in enterprise's value growth. Besides, it should be mentioned, that growth of enterprise's value is considered to be the main indicator of enterprise's activity efficiency in strategic perspective. So, information about elements of enterprise value should be also included into strategic accounting reports.

Analysis of financial and nonfinancial KPI (key performance indicators) is also a crucial element of strategic accounting report.

The interview of twelve managers from six leading Dutch organizations has shown the need of managers in information on competitors and competition, which is usually not available.

So, analysis of literature on problems of documenting process organization for providing information necessary for taking strategic decisions has shown that strategic report is considered to be the main document for providing information for taking strategic decisions. But taking into account that each author gives his own understanding of the content of such report and its essence it is necessary to assume all positive approaches to choose the most appropriate structure of such report on position of all stakeholders of enterprise.

The proposed structure of strategic report is shown on figure 1.

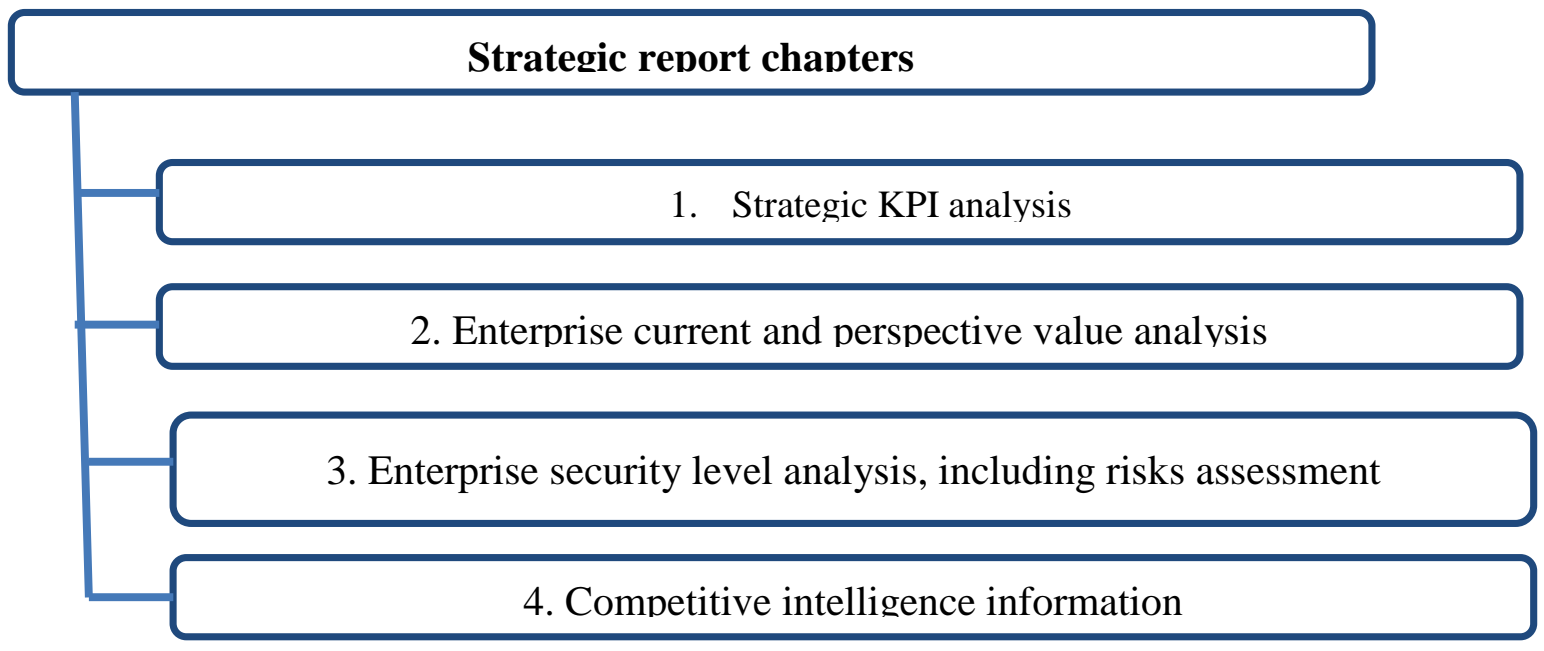

Figure 1. Structure of strategic report

Chapter of strategic report concerning strategic KPI analysis includes analysis of enterprise 
key performance indicators comparing with enterprise strategic goals. The purpose of this chapter is to determine enterprise performance and analyze the level of its correspondence to enterprise strategic goals. If enterprise performance is lower than it was planned in enterprise strategy it gives the possibility to make changes in enterprise activity in order to change performance for better. The analysis of KPI also includes calculation of prognostication indicators which gives the possibility to predict the changes in KPI in future in order to make in time correcting changes in enterprise activity to achieve strategically planned results. Strategic KPI analysis information differs from information given by financial analysis because it gives the possibility to make the prognosis for future using current and historical information on enterprise activity taking into account strategic goals of enterprise. Such analysis is more valuable as it gives the possibility to consider owners interests in enterprise performance.

The second chapter of strategic report - Enterprise current and perspective value analysis gives information which is the most interesting for owners and potential investors. Enterprise value in this chapter can be calculated by four methods of value calculation in order to give more complex information about enterprise for different groups of users.

The third chapter is very important, because it gives information on internal and external risks of enterprise activity, which is necessary to assess in order to choose right decisions in strategic perspective. It also includes assessment of enterprise security level, which makes possible evaluation of enterprise treats and weaknesses and to choose the direction of situation improvement in future.

In conditions of competitive external environment it is important to understand the plans of competitor to predict his decisions and to choose proper response of enterprise to stay competitive on the market. Information about competitors is given in the fourth chapter of strategic report.

Such structure of strategic report is good enough to give all the necessary information for owners, potential investors, managers and other enterprise stakeholders to monitor the results of enterprise strategy implementation, to evaluate enterprise situation on the market and to make prognosis of its further development. Strategic report should be prepared on the year basis and be the part of enterprise annual report.

But its separate parts concerning strategy implementation correspondence to strategic plan should be prepared once a month according to the planning calendar (figure 2).

The results of strategy implementation should be reported at monthly meetings. Monthly strategy meetings don't need to take a lot of time - 30 to 60 minutes should suffice. But it is important that key team members report on their progress toward the goals they are responsible for - including reporting on metrics in the scorecard they have been assigned. By using the measurements already established (KPI), it's easy to make course corrections if necessary.

Conclusions. Thus it can be assumed, that strategic accounting is very important element of effective strategic management. To perform its function strategic accounting information should correspond to strategic goals of the firm. To be useful for enterprise stakeholders, strategic accounting information should include information on business valuation, information on enterprise financial and economic security, information on competitive intelligence, and also information on strategy implementation results, which can be assessed by KPI.

The most appropriate form for strategic information preparing is enterprise strategic report, which should be prepared on the year basis as a part of enterprise annual report. But separate element of this report (KPI of strategy implementation results) should be prepared on monthly basis and discussed with strategic planning team according to planning calendar.

Concerning the responsible persons - departments of financial analytics and economic security department should be responsible for strategic report preparation.

Perspectives of further researches in this direction are connected with choosing KPI of strategy implementation analysis and parameters, which should be reflected in the other three parts of strategic report. 


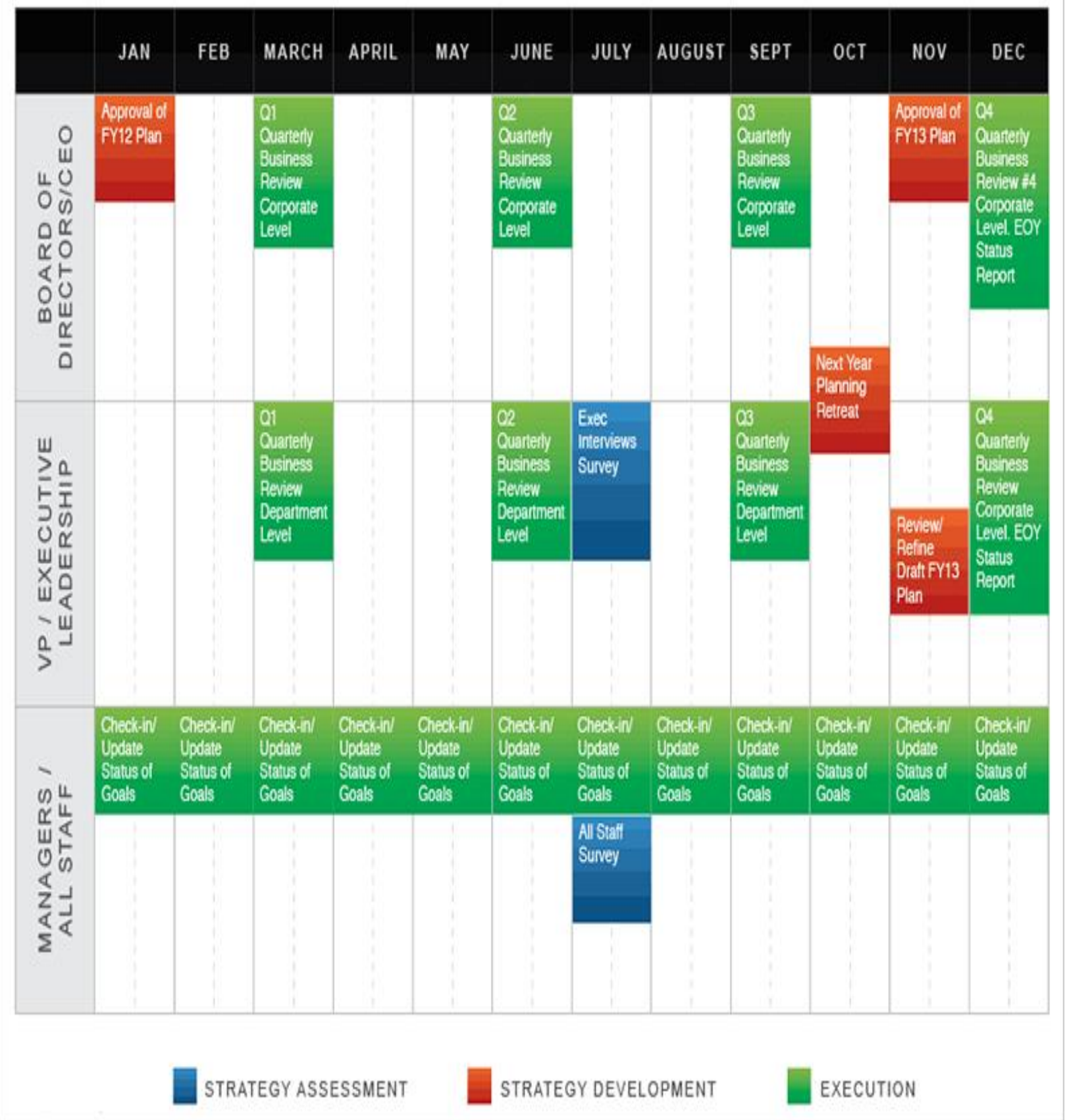

Figure 2. Implementation schedules for strategic plan and its monitoring in strategic report

\section{References}

1. Ernst \& Young LLP (2018) Shining a Light on a Strategic Report. Global Limited. London, UK, 8 p.

2. Financial Reporting Council (2018) Guidance on the Strategic Report. Lexis House, London, UK, 99 p.

3. Keith D. Brouthers, Frans A. Roozen (1999) Is It Time to Start Thinking About Strategic Accounting?. Long Range Planning, Vol. 32, No. 3, pp. 311-322.

4. Matt Chapman (KPMG) (2014) A Practical Guide to the Strategic Report. Better Business Reporting, $\mathrm{UK}, 20 \mathrm{p}$.

5. Graham Simons Pitcher Management Accounting in Support of the Strategic Management Process, CIMA Executive Summary Report. Volume 11. Issue 1, p. 20.

6. Nixon, B. and Burns, J. (2012) The paradox of strategic management accounting, Management Accounting Research, 23:pp.229-244.

7. Stocken, P. C. (2012) Strategic Accounting Disclosure, Foundations and Trends R in Accounting, vol 7, no 4, pp. 197-291. 
8. Okoli Margaret Nnenna (2012) The Use Accounting Information as an Aid to Management in Decision Making. British Journal of Science. Vol.5 (1). P. 52-62.

9. Jennifer VanBaren (2017) What Is Strategic Management Accounting? Bizfluent: Leaf Group Ltd. Available at: https://bizfluent.com/facts-6755021-strategic-management-accounting-.html

10. Cadez Simon, Guilding Chris (2008) Strategy and strategic management accounting: an investigation of organizational configurations. Available at: https://research.mbs.ac.uk/accounting-finance/ Portals/0/docs/2008/CadezandGuilding2008-MBSseminar.pdf

\section{Калефах Ахмед Мухаммед,}

Харківський національний економічний

університет імені Семена Кузнеця

\section{СТРАТЕГІЧНИЙ ЗВІТ ЯК ІНФОРМАЦІЙНО-АНАЛІТИЧНА ОСНОВА СТРАТЕГІЧНОГО УПРАВЛІННЯ}

Проблема. Щоб відповідати вимогам стратегічної управлінської інформації, вона має бути стратегічно орієнтованою. Це означає, щз вона повинна включати не тільки оцінку й відображення активів, зобов'язань та фінансових результатів підприємства у попередніх звітних періодах, а й враховувати такі аспекти діяльності підприємства, як оцінка відповідності результатів підприємства стратегічним цілям підприємства, оцінка ефективності системи управління підприємством та інші оцінки стратегічних параметрів бізнесу. Беручи до уваги достовірність інформачї для прийняття стратегічних рімень та моніторингу стратегічних результатів, важливо визначити інформачію, необхідну на кожному етапі стратегічного управління для кожної групи зачікавлених сторін, спосіб їі представлення та відповідальних за це осіб.

Метою статті є дослідження прочесу документування стратегічної підготовки облікової інформацї та ї̈ роль у системі стратегічного управління. Основними завданнями є: уточнення змісту кожного елемента стратегічної облікової інформачї; визначення змісту стратегічних звітів; аналіз періодів і частоти їх подання.

Методи. Основні наукові методи, які використовуються для досягнення иілей статті, такі: аналіз, синтез, порівняння та класифікачія.

Результати. Аналіз літератури з проблем документування організації процесу надання інформації, необхідної для прийняття стратегічних рімень, показав, що стратегічний звіт вважається основним документом для надання інформаиї̈ для прийняття стратегічних рішень. Але з огляду на те, щзо кожен автор дає власне розуміння змісту такого звіту та його сутності, необхідно визначити позитивні підходи до вибору найбільш доцільної структури такого звіту з позицій всіх зацікавлених сторін підприємства. Запропонована структура стратегічного звіту включає такі розділи: стратегічний аналіз; поточний та перспективний аналіз вартості підприємства; оцінка рівня безпеки підприємства. Така структура стратегічного звіту $\epsilon$ достатньою для надання всієї необхідної інформачії власникам, потениійним інвесторам, менеджерам та іншим зацікавленим особам підприємства для моніторингу результатів впровадження стратегії підприємства, оиінки ситуаиії на ринку підприємства та прогнозування ії подальшого розвитку. Стратегічний звіт повинен бути підготовлений на рік $i$ бути частиною річного звіту підприємства. Але окремі його частини, які стосуються відповідності стратегічного плану реалізащії стратегії, повинні бути підготовлені один раз на місяиь відповідно до календарного плану.

Наукова новизна. На відміну від інших досліджень у иьому напрямі, дане дослідження дає складну структуру стратегічного звіту, який враховує інтереси та потреби в інформачії всіх груп заиікавлених сторін і самого підприсмства для досягнення планових стратегічних результатів. Наприклад, стратегічна інформачія КРІ аналізу відрізняється від інформаиії, наданої фінансовим аналізом, адже дає можливість прогнозувати майбутне з використанням поточної та історичної інформації про діяльність підприємства з урахуванням стратегічних иілей підприємства. Такий аналіз є більш циінним, бо вможливлює врахування інтересів власників у діяльності підприємства. Із позицї інвесторів дуже важливо оцінити майбутню вартість підприємства, але цей аспект не був врахований у попередніх дослідженнях. У попередніх дослідженнях були розглянуті лише окремі моменти, що стосуються безпеки підприємства, в иьому дослідженні рекомендується приділяти більше уваги і розраховувати більще параметрів рівня безпеки підприємства, щяо особливо важливо для підприсмства та його зачікавлених сторін в умовах нестабільного зовнімнього середовища. 
Четвертий розділ стратегічного звіту, запропонований автором, практично не враховується іншими дослідженнями, хоча иуе дуже важливо в умовах конкурентного ринку.

Висновки. Стратегічний облік $е$ важливим елементом ефективного стратегічного управління. Для виконання своєї функції стратегічна облікова інформація повинна відповідати стратегічним ичілям фірми. Щоб бути корисними для зачікавлених сторін, стратегічна інформація $з$ обліку повинна включати інформацію про очінку бізнесу, інформацію про фінансово-економічну безпеку підприємства, інформаџію про конкурентоспроможну інформацію, а також інформацію про результати реалізації стратегії, які можна оцінити за КРІ. Найбільщ доцільною формою підготовки стратегічної інформації $\epsilon$ стратегічний звіт підприємства, який повинен бути підготовлений на основі річного звіту підприємства. Але окремий елемент иьього звіту (КРI результатів реалізації стратегіï) повинен бути підготовлений щзомісяця $i$ обговорюватися 3 командою стратегічного планування відповідно до календарного плану. Щодо відповідальних осіб відділи фінансової аналітики та департаменту економічної безпеки повинні відповідати за підготовку стратегічного звіту.

Ключові слова: процес документації; стратегічний звіт; стратегічна облікова інформація; стратегічний менеджмент; аналіз КРI; інформація про оцінку бізнесу; інформація про фінансовоекономічну безпеку підприємства; інформація про конкурентні позищї.

Одержано редакиією: 14.01.2019 Прийнято до публікаџіï: 22.01.2019 